\title{
HET KOPPENSNELLEN IN ZUID NIEUW-GUINEA
}

DOOR

\author{
P. VERTENTEN.
}

Spreekt men van Zuid Nieuw-Guinea, van de kaja-kaja's, dan denkt men onwillekeurig aan het koppensnellen. Niets wat èn den vreemdeling èn den Marind an e $m$ zelf méér interesseert dan dat.

Het is en blijft een vreeselijk barbaarsch gebruik. En toch, het woord koei $=$ sneltocht is voor den wilde vol poëzie.

De slachtoffers vangen, hunne namen te weten komen, ze snellen, dát is hoofdzaak en doel, maar de reis op zich zelf is voor hen bijzonder interessant: vreemde gewesten zien, de geheimzinnige plaatsen waarvan zij de ouderen hoorden spreken, de bosschen betreden die zij tot nog toe slechts in hunne verbeelding zagen wanneer bereisde mannen er over vertelden, hoe aantrekkelijk! Het dorp, 't bekende — ál te bekende - land verlaten en een paar maanden uitgaan op avontuur, naar den vreemde waar men veel nieuws en moois zien zal, en last not least: waar men zich kan onderscheiden, waar roem en eer te behalen is!

Gevaar is niet uitgesloten, maar dat houdt niemand terug, integendeel: geen $\mathrm{kaja}^{2}$ wil gaarne voor saham (kangoeroe $=$ lafaard) uitgescholden worden, maar is fier op den naam basik= varken, omdat een varken het symbool is van dapperheid: een varken valt aan, weert zich met doodsverachting tegen den aanvaller. Driftig zijn, jareet, iemand die zijn man staat, een die niet wijkt, dat is hier je ware! een der kwaliteiten - zoo niet de grootste - die waarde geven aan een mensch.

Welnu op sneltocht meer dan elders kan men zijn durf en zijn moed toonen.

\section{Waarom snellen ze?}

Wij hebben dat honderden malen gevraagd aan oud en jong, aan kalme, zachtmoedige en ruwe wreedaardige typen. Ik heb 
het gevraagd met versch gesnelde hoofden voor mij. Waarom toch? Steeds was het stereotype antwoord: igiz nango $=$ om namen te hebben.

Een kaja ${ }^{2}$ heeft verschillende namen, meest bijnamen, ontleend aan zijn totem, ontleend ook aan uitroepen of scheldwoorden uitgesproken bij bijzondere gelegenheden bijv. toen vader hem verwekte, bij een of ander voornaam feit of feest. Sommige namen waren ontleend aan een typisch woord, een strijdkreet of een leuze uitgesproken op sneltocht bij het vangen van een man (hakev-rikigiz), bij het afstroopen van de scalp (kahasib-rik igiz), bij het dragen van den gesnelden kop

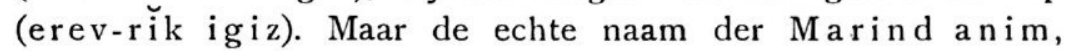
de igiz-ha is de koei-of pa-igiz=de snel- of kopnaam, de naam der gevallenen.

Daar zijn zij fier op! Ik zie nog de kleine jongens van Doevmiraav vóór mij, hoe zij mij levendig vertelden van den ouden grijzen $\mathrm{Kenda}$, hoe hij de jonge mannen nog aanspoorde om te gaan snellen. "Toean» zeiden ze - en fier klopten zij zich op de borst - wij hebben allemaal nog kopnamen. Koe i is slecht, snellen mag niet. Kenda is oud, zijne oogen beginnen te schemeren, koei tiske nama, 't zal nu uit zijn met het snellen!,

Voor elken kaja ${ }^{2}$ is een menschenoffer gevallen, een man of vrouw gesneld! Dat is niet overdreven, want al is het waar, dat soms twee personen naar één kop genoemd werden, waar is ook dat sommige brani's, die zoogenaamd boften, koppen en namen over hadden. Zoo o.m. de oude Jadjo van Okaba. Hij had zeven kinderen, zorgde dat elk kind een kopnaam had en hield toen nog drie namen over. Omdat hij in ons goede vrienden zag, goede menschen: waningap anim, was hij bereid ons elk een dier namen af te staan!

What is in a name? Voor hen is een naam - vooral de echte of kopnaam - meer dan voor ons. $\mathrm{Zij}$ voelen zich één daarmee. Toen $\mathrm{Nalwo}$ van $\mathrm{Okaba}$ gaarne den naam van Pastoor Nollen aannam, deed hij juist alsof hij zijn eigen persoon uittrok, hij streek met de handen over de armen, borst, buik en beenen en deed alsof hij Nalwo uitdeed, weggooide en Nollen aantrok!

Een kopnaam dat beduidt: „voor mij is vader, oom of grootvader vér weg geweest op sneltocht, om mij dien naam te halen heeft hij veel gevaar getrotseerd. Hij was dapper en vlug en 
ving een mensch voor mij. Zóóveel was ik hem waard! voor mij is een binnenlander gevallen!"

Dit is zeker, dat men er véél voor over heeft om een kopnaam te halen, men moet vér gaan, levensgevaar komt er meer dan eens bij en vaak komt een man onverrichter zake terug. De kopnaam moet ontnomen zijn aan een slachtoffer dat men zelf ving (dat men het zelf onthalsde was niet noodig); het bewijs neemt men mee naar huis in den vorm van een gesnelden kop. Valt de kop uiteen, dan moet men ten minste het kinnebak bewaren, dát is het bewijsstuk.

Toen ik aan den kleinen Boedeiam van Okaba vroeg of zijn naam een snel-naam was (zijn vader had nog geen succes gehad), was zijn antwoord bevestigend.

En wie heeft dan een naam voor $U$ gehaald?

Amei, Toean, mijn grootvader, Kombida, al lang geleden. 't Kinnebak bewaart vader in de ogatok-wad! (de ogatok$\mathrm{w}$ ad is eene groote, diepe, van biezen gevlochten beurs, waarin men de kostbaarheden bewaart, zij wordt in den nok van het huis opgehangen). Versch behoeft een naam dus niet te zijn, hoe oud ook, hij behoudt zijne waarde.

De vader stelt er eene eer in zelf namen te hebben of te halen voor zijne kinderen. Niet allen echter hebben succes, niet allen hebben een kopnaam klaar voor een pasgeboren kind. Maar dan is er meestal wel een oom of grootvader die nog één in voorraad heeft. Later als vader zelf succes heeft krijgt de kleine wel een tweeden kopnaam. Zóó gebeurt het dat één kind twee, drie en meer snel-namen heeft, vooral wanneer de familie groot is en er slechts een paar kinderen komen. Dat zijn echter uitzonderingen.

Nog dient opgemerkt dat voor hen een naam mannelijk noch vrouwelijk is, de oorsprong doet dus niets ter zake en men kan elken kopnaam zoowel aan een meisje als aan een jongetje geven. Zóó had men in Okaba een man en eene vrouw van denzelfden leeftijd, beiden heetten Maboeda, zij hadden die namen van één en denzelfden kop, za kod-parik. Dat gebeurde meer, dat men éénzelfden naam gaf aan twee kinderen, ook gebeurde het dat men van één gesnelde twee namen te weten kwam: dat was oentoeng. Maar als een véél grooter succes gold $5,7,10$ en meer koppen te hebben en zóó namen in voorraad te houden. 


\section{Waar gaan ze op sneltocht?}

Men vergete niet dat ik steeds spreek van de Marind-anim. Diep in het binnenland snellen. de verschillende stammen elkander onderling.

De Marindinees verdeelt de menschheid in drie groepen:

De anim-ha: de echte menschen - en dat zijn zij.

De $\mathrm{ik}$ om: de andere bewoners van Zuid Nieuw-Guinea waarmee $z$ ij in vijandschap leven of liever waarmee zij nog niet bevriend zijn.

De poe-anim of vreemdelingen.

De ikom zijn volgens hen geen echte menschen: minderwaardig in elk opzicht! Een Romein kon niet met meer verachting op den barbaar neerzien dan een kaja-kaja-übermensch op den ikom. Die zijn alleen maar goed om gesneld te worden. "A nim bake, Toean» dat zijn geen menschen, Toean. Laten wij die toch gaan snellen. Ze zijn niet meer waard!

De bevriende stammen in het binnenland waren vroeger ook $\mathrm{ikom}$, behoorden vroeger ook tot de snelplaatsen.

Het snellen is gedeeltelijk een veroveringskrijg en stil aan werd de grens der bevriende stammen verder verschoven. Met de naaste buren leeft men liefst in vrede, dat makt niet alleen eigen streek veiliger, maar heeft velerlei practisch nut, want de binnenlanders zijn boot- en trom-makers, in hunne bosschen vindt men paradijsvogels en casuarissen en zij brengen gaarne die artikelen, in ruil voor andere, naar het strand, o. m. ook de zoo mooi afgewerkte kleurige pijlen.

Meer dan eens zagen wij vijanden van vroeger nu gezamenlijk wati drinken en elkaar bejegenen alsof er nooit iets tusschen hen geweest was.

Zoo zat eens een oude boschman in Okaba heel knusjes te vertellen uit den ouden tijd, toen Okaba bij hen was gaan snellen: Hij wist nog zeer goed hoeveel er toen gevallen waren. Daar praten ze over als over iets zeer gewoons, net als twee oudstrijders een Belg en een Hollander dat zouden doen over de ruzie van ' 30 .

Toen wij pas in Okaba waren was Makl ̌oe nog snel-terrein van Sangasee, maar reeds bevriend met Doev, Makalin en Okaba.

Dat vrede teekenen is een eigenaardig iets, men heeft geen tusschenpersonen of tolken. $\mathrm{Zij}$ die vrede willen sluiten kruipen tot in de nabijheid van den vijand en deponeeren daar enkele 
geschenken, meest een mandje met kalkkoker en pruimgerei. Wilden de Marind-anim vrede, dan was die er gauw en men hield sinds vrij trouw aan het gegeven woord. Maar soms - en dat was het gemeene - veinsden zij slechts vredelievendheid. Een paar ouden gingen er dan alleen op uit om de vredespruim te pruimen, met vriendelijke gebaren lokten zij de bange menschen. Stilaan kregen deze meer vertrouwen. Ondertusschen omsingelden de snellers de plaats, een of ander teeken der ouden: een tik op een kalkkoker, een bepaald woord of uitroep waren het teeken tot den aanval. En dat noemen zij niet laf maar slim! $\mathrm{Zij}$ lachen om de «stommerikken" die er zóó inloopen!

De groote snelterreinen der Marind-anim waren: de groote Digoel-rivier en het terrein gelegen tusschen de grens van Noord Nieuw-Guinea en de Fly-rivier. De grens van Zuid Nieuw-Guinea valt vrijwel samen met de grenzen van den Marind-stam in het O. en Z.O.

Honderden, duizenden menschen zijn daar in den loop der jaren gesneld. Naar eene vrij juiste schatting woonden alleen aan het zeestrand 15000 . Marind-anim toen de Regeering zich hier vestigde. Aan dat getal beantwoordt een even groot cijfer gesnelde hoofden: één geslacht van de strandbevolking vroeg 15000 menschenoffers!

Dat zulks niet overdreven is blijkt hier uit, dat in een paar jaren tijd van 1910 tot en met 1912 (wij waren toen op Okaba) meer dan 100 versche koppen naar het stand zijn gebracht, alleen door de dorpen gelegen westelijk van de Bian tot en met Wambi.

In de nadere bepaling, welke zij-rivier zij zullen invaren, welken stam, welk dorp zij zullen aanvallen, lieten zij zich dikwijls leiden door wraakgevoel. Plaatsen waar zij vroeger op sneltocht volk verloren, komen zeker weer eens aan de beurt.

Toen Alakoe in 1911 uittrok, had ook Mewi veel lust om mee te gaan. Alakoe noodigde ze uit en het groote motief dat zij aanhaalden was: johan heis ipe $=$ daar zijn ginds overleden dorpsgenooten m. a. w. daar zijn vroeger van de uwen gevallen, wreekt ze.

De groote sneltochten hadden dus plaats op de verre snelterreinen, de koei-mirāv. Maar tusschen door, wanneer zij de kans schoon zagen, snelden zij ook wel een of meer menschen uit kampongs van eigen stam of bevriende binnenlanders.

Dl. 79 . 
Zoo weet men nog te vertellen hoe de vader van Sok iwag van $\mathrm{Okaba}$ een geweldig koppensneller was, tuk op koppen en onvervaard. Wanneer bosch-bewoners naar het strand kwamen ging hij bij hun terugkeer in hinderlaag liggen en overviel een of anderen achterblijver. De koppen hing hij in zijn tuin!

Nowari, het eerste dorp ten Z.O. van Merauke had een kwaden naam. Dikwijls kwamen reizigers daar voorbij op weg naar Kanoem of elders om daar bij een vriend matten en mandjes te halen. In gezelschap reizend was er minder gevaar. Ging één of twee man ver op het strand voorbij (zij liepen nooit dicht bij de dorpen uit vrees voor tooverij) dan wenkten mannen van $\mathrm{Nowari}$ vaak die reizigers, ze uitnoodigend even te komen pruimen en praten. Was het eene goede kennis, dan hoorde men weer eens nieuws, tracteerde hem en liet hem ongestoord verder gaan. Was het iemand van verre, waar wel geen haan naar kraaien zou, dan overviel men den ongelukkige op een gegeven teeken en snelde hem. Dat is niet eens maar herhaaldelijk gebeurd!

Het groote Sangasee (dat van de imo sekte is) overviel eens de majo's (eene andere geheime sekte) van Makalin in hun inwijdings-tijd. Zóó hadden ze gemakkelijk spel. 't Was meteen eene verachting van en uitdaging aan de majo's.

Toen Pastoor $\mathrm{H}$. Nollen nog niet lang hier was en er een groot feest gegeven werd aan het strand, waren vele kaja-kaja's van heinde en verre daarheen gekomen. Daarom waarschuwde men den Pastoor liefst langs het strand terug te keeren. Er waren nu zoovele vreemden in de tuinen en allicht kon een of ander in zijn hoofd krijgen hem te snellen, wanneer hij zoo alleen en ongewapend door de tuinen ging.

Eens gingen drie ewatis (jongelui) naar $\mathrm{Kan}$ oem (voorbij Sarire) om slaapmatten te halen. In Borem kregen zij oneenigheid met lui van $\mathrm{Kan}$ oe $\mathrm{m}$, die hun drinkwater weigerden. Dat was voldoende reden om verontwaardigd naar Nowari terug te keeren. 's Nachts in het geheim steekt in stilte een boot vol gewapende mannen en jongelui in zee, ze boomen langs de kust tot voorbij Borem, verstoppen hun boot bij Bokem (eene kleine kreek) en gaan in hinderlaag liggen om kan oe m a nim te vangen, die zeker daar langs zouden komen naar het feest. Afzonderlijke personen of een klein gezelschap van twee, drie menschen noodigen zij uit zich wat te zetten en te pruimen, 
samen zullen ze dan naar Borem gaan! Zoo overvallen zij heel wat menschen en verbergen de lijken een eindje verder in struiken en gras. 's Nachts varen zij met een boot vol koppen naar Now a ri. Later moest heel het dorp boeten om die gemeene streek van enkelen.

\section{Wie gaan op sneltocht?}

Dat hangt veel af van de omstandigheden van plaats en tijd. Willen ze heel gauw terug zijn, dan gaan alleen sterke volwassenen mee.

$\mathrm{Zij}$ die over de Engelsche grens gingen snellen moesten hiermee rekening houden, dat daar weinig of geen sago is en weinig klappers. Van de aardvruchten der bewoners konden ze eerst profiteeren wanneer er gesneld was, en dan nog niet lang.

Daarom ging van de dorpen ten Z.O. van Merauke slechts eene keurbende uit: meest jonge kerels, sterke vrouwen, een paar ondervindingrijke maar nog kranige ouden en iwag, jonge meiden die niet langer konden wachten zóó verlangden zij de groote reis mee te maken.

Aan den overkant der Merauke-, Koembe- en Bian-rivieren vooral in het $\mathrm{Okaba-district} \mathrm{trok} \mathrm{men} \mathrm{er} \mathrm{lustig} \mathrm{met} \mathrm{heel} \mathrm{de}$ dorpen op uit. Bij de Digoel-rivier is sago in overvloed. Was de voorraad op dan bleef men een paar dagen om meel te bereiden en trok dan weer verder.

Toen Alakoe eind November 1911 op sneltocht uittoog bleven alleen enkele oudjes en zieken te huis. Twee maanden bleven de snellers uit en keerden eerst 5 Januari 1912 in het dorp terug.

\section{Wanneer snellen ze?}

De droge tijd was voor hun doel het meest geschikt, vooral het eind van den drogen tijd. Elk jaar moeten er nieuwe tuinen gespit worden, ook dat moet gebeuren in het droog seizoen, wanneer het water weggetrokken is uit de lage leemgronden. Ze maakten daar meer spoed mee, wanneer tot een sneltocht besloten was; in November vertrokken ze dan meest en kwamen bij de eerste regens (eind December, begin Januari) terug. Soms ging men vroeger om dan na den sneltocht aan het zware tuinwerk te gaan, maar men begrijpt dat men daar minder voor voelde, want de ondervinding leerde, dat er dan niet veel meer van tuin-aanleg kwam. 
De droge tijd was wél aangenaam om te reizen: de moerassen waren dan uitgedroogd, er waren geene muskieten en men had geen last van den regen, zoodat men gerust onder den blooten hemel slapen kon en een bivak gauw klaar was.

Meestal heeft men hier een lang en zeer droog seizoen, en dát is je ware. Toen het in 1911 zoo geweldig uit het Z.O. bleef waaien en alles dor werd, zei onze vriend $\mathrm{Kalmoe}$ van Mewi tot ons: "Toean, zegt aan Toehan Allah dat hij het regenen doet anders gaan de menschen zeker op sneltocht!, en ze gingen op sneltocht!

't Was dus regel: in den Oost-moesson was het snel-tijd. Maar ook op dezen regel waren uitzonderingen: soms was de hooge waterstand in het regen-seizoen eene aanleiding om vlug en goed per boot een tocht te wagen en geen kwaad vermoedende binnenlanders te overvallen.

\section{De voorbereiding.}

't Zijn gewoonlijk de mannen van één mannenhuis (otiv) onder de leiding van één invloedrijke die tot een sneltocht beslissen. De namen zijn op, ‘igiz mendap ba rèn ", men moet dus nieuwen voorraad opdoen.

En ook al hebben ze nog een paar namen over, er zijn altijd jareet-anim, vurige karakters, avontuurlijke overmoedige kerels, belust op moord en roof en roem. Elk mannenhuis had zijn eigen naam en dat moest door een groot feest weer eens van zich doen spreken.

In Jobar was indertijd Papoes-ngat de meest gevierde jonge man, het initiatief tot verschillende snel-partijen op Engelsch gebied ging van hem uit. Eind 1910 heb ik zelf in Jobar het koppenfeest mee gemaakt waar Pa poes-ngat de gevierde was (hij was toen nog ewati). Koppen hebben wij niet gezien en zekerheid van een sneltocht had men niet, eerst veel later kwam ik dit alles te weten. Het bestuur controleerde toen nog al te weinig het doen en laten der kaja's en men dacht er niet aan, dat, terwijl bekende typen uit de dorpen zich geregeld in Merauke lieten zien en de kampongs heelemaal niet verlaten schenen, eene groote keurbende lustig en rustig op sneltocht ging.

Op een goeden avond, onder het kauwen en drinken van een potje wati kwam dus een man met het voorstel. Hij had 
er al over nagedacht, en zei kort weg: de namen zijn op, laten wij op sneltocht gaan en die of die verslaan!» Aanstonds was er bijval. Men sloeg aan 't beraadslagen: welken stam? niet liever dit of dat dorp? en wanneer? eerst zou men met de tuinen klaar moeten zijn! De ouderen, de levende geschiedboeken werden geraadpleegd; na alles gewikt en gewogen te hebben stond het besluit vast: dáár gaan we heen, die moeten er aan, wanneer de omstandigheden het plan niet wijzigen. Heel het reisplan wordt al opgemaakt. In langen tijd ging men dáár niet op sneltocht, men heeft dus alle kans er weer volk aan te treffen. 't Is meteen wraakneming om de dorpsgenooten, die men daar bij een vroeger treffen verloor!

Den volgenden dag is er algemeene raad, al de mannen zitten bijeen op de open plaats achter het dorp in de schaduw der klappers, men praat druk, zij die met het voorstel aankwamen oogsten nu reeds eer en bewondering. Weldra weet heel het dorp groot en klein het groote nieuws. Aller fantaisie werkt, men denkt aan niets anders, spreekt over niets anders.

De jongeren, die nog nooit meegingen vooral, branden van verlangen om mee te gaan, benijden hen die mee mogen. $Z_{i j}$ hooren nu voortdurend namen herhalen die zij reeds dikwijls hoorden (immers al de varkens uit het dorp dragen namen van snel-plaatsen, dorpen en stammen waar men koppen haalde) maar nooit met zooveel détails. Hoe verleidelijk was een sneltocht voor hen, die de meeste dagen van hun leven sleten in eigen dorpje en eigen tuinen. Men ging wel eens naar een feest in een naburig dorp, ook wel eens ver, maar alle stranddorpen lijken op slot van rekening veel op elkander.

En zij die reeds op sneltocht togen verlangden al even hard die plaatsen weer te zien. $\mathrm{Nu}$ nog verlangen zij daar naar.

Wanneer zij in het begin van den drogen tijd de ambata (= pijl) des avonds schitterend in het Z.O. zien opkomen ( $\beta$ en « van Centaurus) dan gaat nu nog hun hart open bij de herinnering aan de plaatsen die daar liggen in die richting en die zij $U$ achtereen opnoemen.... wondere plaatsen van deema's, rijk aan legenden, die zij vroeger bezochten op sneltocht.....

"Toean» zeiden mij de mannen van Oeroem claten wij er nog eens heengaan, gaat $U$ mee, wij zullen niemand snellen, alleen maar om die streken weer te zien!»

Van nu af bereidt ieder zich reeds voor op den tocht. Eerst 
worden de tuinen afgewerkt. De vrouwen kloppen veel sago in voorraad, de mannen maken bogen, pijlen, kalk- en waterkokers, zelfs boogpezen maakt men in voorraad. ${ }^{1}$ )

Elken morgen is er in het dorp a jase e: de mannen, vooral de ouderen zingen een indrukwekkenden sonoren zang begeleid door zwaren tromslag op de groote kandara's (trommen) met kangoeroe-vel bespannen. Men hoort dat ver. Het brengt allen nog meer in stemming en in de buurt zegt nu ieder: choor je den ajasee? sneltocht binnenkort!, Die tromslag wekt in een kaja hart gevoelens van bewondering, van sympathie en verlangen.

\section{Het vertrek.}

Ging men rechtstreeks het binnenland in, dan moest alles gedragen worden en werden soms vivres vooruitgestuurd.

Langs de kust gebruikte men de groote lange booten (uitgeholde boomstammen), vulde ze met allerlei eetwaren vooral sago, klappers en pisang. De sago werd goed afgedekt met boomschors van boes (kajoe-poetih) opdat regen of zeewater die niet bederven zou.

Enkele mannen boomden die booten (niet ver in zee). De andere mannen en vrouwen gingen te voet aan het zeestrand, de vrouwen beladen met allerlei leeftocht, pruimgerei enz.

Bij den uittocht begeleidden de achterblijvers een eind ver de vertrekkenden, hielpen zoover de zaken dragen en namen dan afscheid met tranen in de oogen. $\overline{\mathrm{E}} \mathrm{h}$ ! êh! klonk het dan van beide kanten. Gaat! — blijft! — gaat! — wij zullen weer komen! Nog lang staarde men de dierbaren na, weenend vaak, ook de vertrekkenden waren onder den indruk, maar weldra maakte die weemoed plaats voor opgewekter stemming.

Sommige achterblijvers legden knoopen in een touw: 40, 50, 60 naar gelang de dagen, dat zij vermoeden, dat de tocht wel duren zou. Elken dag werd een knoop losgemaakt.

Anderen staken zooveel stokjes in een sago-stengel en trokken er elken dag een stokje uit.

Nog anderen rekenden volgens den maan-stand.

1) Op jacht of sneltocht dragen vele mannen eene nieuwe boogpees om den buik gebonden, springt eene pees dan heeft men anstonds eene andere nieuwe, goed op maat, bij de hand. 


\section{Op reis.}

Elke dag brengt afwisseling: steeds ziet men nieuw terrein. De ouderen weten waar waterputten zijn en wilde vruchten. Haast heeft men niet. Onderweg wordt gevischt op vischrijke plaatsen. Zoo wist Bonang van Boeti over de Engelsche grens eene plaats rijk aan groote krabben. Men maakt jacht op casuaris, varkens, kangoeroe's, vooral warev (eene kleine kangoeroe-soort die veel voorkomt in 't binnenland).

Zij die naar de Digoel gingen kwamen kloek, sterk en wel doorvoed terug. Dáár is eten in overvloed.

Zij die naar de Western-division in Papoea trokken moesten vaak veel ontberen, vooral wanneer de voorraad sago op rakkte, maar een kaja $^{2}$ weet zich te behelpen, schikt zich naar de omstandigheden en.... gaat zelfs groot op doorstane miserie. (Tout comme chez nous!)

Met een bivak is men spoedig klaar: enkele stokken in den grond en daarover wat boomtakken, gras of palmbladeren, meer niet! Soms stellen zij zich tevreden met eene kleine omheining die tegen den kouden nachtwind beschut.

Onderweg sluiten zich vaak - naar afspraak - bevriende boschbewoners bij hen aan.

De Digoel-rivier stak men met booten of vlotten over, had men booten genoeg dan voer men een der zijrivieren in want de bevolking woont daar meest aan de zijrivieren en wel aan den oorsprong.

Op Engelsch gebied voer men Morehead-rivier op of eene of andere kali, zoover mogelijk, maakte daar een bivak op eene goede veilig-verkende plaats en trok van daaruit verder het land in.

\section{Aankomst op het snelterrein.}

Niemand beter dan deze menschen ziet waar eene plaats bewoond begint te worden. $\mathrm{Z}_{\mathrm{ij}}$ zien het aan de javoen-kai de z.g. bootwegen in riet en gras door de booten gevolgd wanneer alles onder water staat. $\mathrm{Zij}$ zien het aan kleine paden in het bosch, die wij niet zouden opmerken, aan een achter gelaten boot, een vischfuik, een verlaten tuin, gekapt hout enz., zij weten goed het onderscheid tusschen oude en versche voetsporen. 
Van nu af moeten zij zeer voorzichtig zijn, anders wordt het volk in de buurt gewaarschuwd, dan zijn zij heelemaal niet meer te vinden en is de tocht mislukt. Wat meer dan eens voorkwam.

Daar komt dan bij dat ze zelf niet veilig meer zijn, en zij - brani zoolang ze niets te vreezen hebben - worden echte saham's (= kangeroes $=$ bangerikken) wanneer de tocht gevaarlijker wordt. $\mathrm{Zij}$ keeren dan vaak maar liever onverrichter zake terug.

Zoo is het dorp I wolje in 1910, 1911 en 1912 driemaal te vergeefs naar de Digoel geweest en werd uitgelachen! Zelf hadden zij er een paar menschen bij ingeschoten (wier lijken zij echter niet ginds lieten maar meebrachten om ze te begraven in eigen grond).

Eens, vertelt de geschiedenis, was een heel dorp op sneltocht getogen en men heeft er nooit iemand van weergezien.

Gevaar bestaat er dus wel. Ook bij het overrompelen van een dorp vallen van de zijde der aanvallers meer dan eens dooden. 't Is kaja ${ }^{2}$ wijsheid: zorg zooveel koppen mogelijk mee te brengen, maar verlies uw eigen kop niet! Daarom gaat men niet roekeloos maar zeer omzichtig en voorzichtig te werk en worden de ouderen voortdurend geraadpleegd.

Met vuur zijn zij zeer voorzichtig overdag want dan ziet men heel ver den lichtblauwen rook. 's Nachts zijn zij veel geruster op dat punt en poffen kalm hun voetsel op knetterende vuurtjes. Als 't vuur maar niet te groot is, zal het hunne aanwezigheid niet verraden, bosschen en struiken verbergen het dan voldoende.

Op de rivieren gaat steeds één boot in de grootste stilte voorop. De aandacht der instaanden (ze roeien staande) is voortdurend gespannen en niets ontgaat hun.

Zij kampeeren liefst op meer als zoodanig gebruikte atid (pleisterplaatsen). Ze verkennen steeds goed den omtrek en weten gauw of ze al dan niet op hunne hoede moeten zijn.

Zijn zij dicht genoeg genaderd, dan zullen zij voorzichtiger zijn dan ooit en eerst na zorgvuldige verkenning gezamenlijk weer opbreken om hun laatsten beslissenden slag te slaan.

\section{Op verkenning.}

Hij die den sneltocht uitschreef en nog een paar dapperen moeten er nu op uit om het terrein te verkennen. $\mathrm{Zij}$ gaan niet langs de paden maar door bosch en struiken, door moerassen, riet en gras, door modder en grachten. Gezicht en lijf 
wrijven zij in met kalk en binden waaiervormige kransen van casuaris- en paradijsvogelvederen op het hoofd. Dat maakt iemand in het dorre gras, riet en struiken zoo goed als onzichtbaar. Zonder dat zou hun bronzen figuur als een al te scherp profiel zich afteekenen in de vlakte.

Sommige verkenners maken zich eene kap van kajoe-poetihschors, opdat, wanneer zij zichtbaar zouden worden, men ze houden zou voor eene vrouw met de kapmat op het hoofd, zooals de binnenlandsche vrouwen gewoon zijn te dragen. Zulke verschijning wekt minder argwaan.

En op den koop toe worden de verkenners nog onzichtbaar gemaakt met tooverspreuken: gamo. Alvorens te vertrekken moet een kenner ze overprevelen. Nu kunnen zij gerust gaan, niemand zal ze zien! Voorzichtig sluipen zij verder, gewapend met boog en knots. Vinden zij één of twee menschen die zij zonder alarm besluipen kunnen dan snellen ze die al vast. Hoofdzaak is het terrein te verkennen, te zien of en hoeveel menschen er zijn.

Sommige driftkoppen pakken wat zij krijgen kunnen. Mislukt dan de tocht in 't algemeen, zij zijn niet voor niets op sneltocht geweest!

Op een sneltocht die een onzer jonge mannen van $\mathrm{Okaba}$ : Diraw meemaakte, kwamen de verkenners terug met de boodschap: niet héél ver (ongeveer 2 uur gaans) ligt een dorp, vrij groot. Een prachtgelegenheid. De menschen zijn kalm en gerust, ze hebben nog niets gemerkt.

-Dus, was de conclusie dezen nacht nog gaan wij er op uit. Men at en dronk goed, slapen wilde men niet, en ging, geleid door de verkenners, beslist op het doel af.

\section{Het snellen.}

Onderweg reeds prevelen de kenners geheime tooverkrachtige formules in de vuist en openen ze onder breeden zwaai over het ongelukkige dorp. Het zijn slaapformules, die de slachtoffers in een diepen slaap moeten dompelen, zoodat zij niets merken van den naderenden vijand.

De meeste vrouwen en kinderen der snellers blijven in het bivak achter. Als algemeene regel trouwens geldt dat de vrouwen niet bij het onthoofden tegenwoordig mogen zijn. Enkele vrouwen gaan mee, die gaarne een kind voor zich willen rooven of in ontvangst nemen wanneer man of broer er een vangt. 
De grootere patoers gaan mee. Aller gezicht wordt met kalk ingewreven opdat men in de hitte van den strijd niet op eigen kinderen pijlen zou.

In de grootste stilte nadert men het dorp langs de verkende paden en omsingelt het. Des nachts snelt men niet, dat is een slechte tijd voor den overval, dan ziet men niet, er zou te veel ontsnappen. Men wacht dan tot het licht is, goed licht, of een onvoorziene gebeurtenis moet den strijd verhaasten.

Wanneer aldus een dorp op sneltocht is en de thuisblijvers weten dat hunne doorpsgenooten op de snelplaats moeten zijn of ongeveer, dan verkeeren ook zij in spanning. Waait het dan des morgens hard van uit het binnenland, dan zien zij daarin een teeken dat er op dat oogenblik gesneld wordt. «Digoel kan isāk», zei men dan, "zij verslaan de Digoelmenschen!,

Als het licht is zijn de snellers in nog nauweren kring het dorp genaderd. Alle paden en uitwegen zijn bezet. Allen zijn gewapend met lansen, bogen en pijlen. Allen hebben de hand aan de boogpees of aan den lanswerper "kandeel" (een soort van weerhaak). Allen zijn bepluimd. Hun gezicht is ingewreven met kalk of roodgebrande aarde. De oogen staan strak, groot en wild, bloedbeloopen van spanning.

In eens hoort men aan alle kanten een uitdagend geroep, de oorlogsverklaring, de snellers slaan zich op de borst en schreeuwen: johan koei ma man eeher zib! = de zoon van $N$. komt om jullie te snellen! de zoon van Mōjoe, de zoon van $\mathrm{Ka}$ mēnap, de zoon van Kawidoe enz. Mak-ēnam nas = laten wij vechten!

Overmoedig zijn ze, vol strijdlust, zeker van de overwinning, veel talrijker en beter bewapend dan de overvallenen.

Bij 't hooren van dat plotseling geschreeuw slaat den armen binnenlanders de schrik om het hart. $Z$ ij verstaan maar al te goed waar het om gaat. Radeloos zijn zij, wanhopig! Zij verliezen het hoofd, werpen zelfs hunne wapens weg, slechts ééne gedachte bezielt allen: wegkruipen in een hoek of trachten te vluchten, men stort zich ijlings in 't gevaar om te ontkomen langs een pad of door het kreupel-hout! Maar als opgedreven wild vallen de meesten, zoo niet allen de belegeraars in handen. De bogen kraken, scherpe pijlen en lange lansen vliegen naar alle zijden, elke sneller schreeuwt zijn eigen jachtkreet. 
Enkele binnenlanders verdedigen zich met den moed der wanhoop, dansend van drift. Dat noemen zij de dapperen. En zóó laat ook meer dan eens een sneller er het leven bij. Op den sneltocht door Dira m meegemaakt vielen 5 Wendoe-mannen. Een ooggetuige van den laatsten sneltocht die $\mathrm{Okaba}$ in 1912 ondernam verzekerde mij, dat $\mathrm{Komab}$, een jonge man, zeker gevallen zou zijn, wanneer hij zelf niet op het juiste oogenblik een pijl had gejaagd in de borst van een man, die vlak vóór hem de lans drilde om hem te doorsteken.

Twee anderen Salahei en Kanga droegen nog de versche lidteekens van groote lanswonden.

Wanneer zij bij de Digoel palen woningen omsingelden, schoten zij op de belegerden en deze van hunnen kant wierpen van boven met lansen. Duurde het wat lang dan schoten de snellers de hooge huizen in brand. Daartoe bonden zij brandende propjes klapperbast aan hunne pijlen. De dorre dakbedekking vatte gauw vlam en de in 't nauw gebrachten stortten zich naar beneden.

't Is gebeurd dat menschen zóó levend verbrandden en halfverkoolde kinderlijkjes naar beneden vielen!

Al dan niet gewond, de slachtoffers worden gevangen en stevig vastgebonden of gehouden. Levend moet men ze in handen hebben, want men moet de namen te weten komen. Nieuwe kopnamen voor de kinderen is hoofddoel van den tocht.

Al wat ongeveer 13 jaar oud is of daarboven, hetzij man of vrouw, wordt onbarmhartig gesneld. Kinderen van 2 tot en met 7 jaar worden meegenomen naar de kust door wie ze bemeesterden en aangenomen als eigen kroost. De vrouwen nemen de kinderen aanstonds op, verwijderen ze van het moordtooneel en overladen ze met eten en goede woordjes.

Zóó kenden wij in Okaba alleen 28 menschen (groot en klein) afkomstig van sneltochten. (Op 250 à 300 inwoners was dat veel). Het laatste kind brachten zij mee in 1912 van heel ver op de Digoel. $\mathrm{Zij}_{\mathrm{ij}}$ mochten het jongetje niet houden, $\mathrm{W}$ angeike werd aan de missie afgestaan en is nu te Langgoer (Kei) op de hoofdstatie. Elk jaar komt hij op vacantie en voelt zich hier te huis. Eens nam ik hem mee naar $\mathrm{Okaba}$ waar hij aller sympathie had en allerlei cadeautjes kreeg! Zijn vader werd gesneld maar had in 't geharrewar van den strijd zijn kind nog weg kunnen duwen in de struiken. Vol schrik en 
angst bleef de kleine daar staan, niewsgierigheid deed hem even de struiken wegduwen en zóó werd hij opgemerkt. Met zijn kinderboogje had hij zich nog willen verdedigen maar men vatte hem. De indruk van die wreede gebeurtenis op zijn kinderzieltje gaf de kleine weer in twee woorden: do otiv = veel bloed! Zuigelingen laat men liggen naast de onthoofde lijken der moeders. Kinderen te groot om mee te voeren en te jong om te snellen laat men loopen. Dat zijn $n$ in zeggen ze: Kleinen, jongen. Laat die maar opgroeien en zich vermenigvuldigen, die krijgen dan later wel hunne beurt!

Diraw vertelde mij, dat zijn vader juist een man te pakken had, terwijl een mooi klein meisje radeloos voorbij vloog. "Grijpt het schreeuwde hij Diraw en de andere jongens toe. Maar deze door 't wreede gebeuren onthutst waren zóó in de war, dat ze in plaats van het kindje te grijpen, zelf het uit den weg liepen en het zóó ontvluchten kon.

Hoe komt men nu den naam te weten van het slachtoffer?

Hoewel de meeste stammen waar men op sneltocht ging eene andere taal spreken, houden de Marind-anim toch vol, dat zij om hun naam gevraagd, dien zeggen.

Een feit is dat ze verschillende Engelsche woorden te weten waren gekomen op Engelsch gebied o.a.: ingris (english) en kow (koe), een lucifer noemden ze vóor onze komst: ingris takav = engelsch vuur!

$\mathrm{Kalmoe}$ van $\mathrm{Me} w \mathrm{i}$, die ons zeer genegen was en ronduit alle zaken met ons besprak heeft ons eens aanschouwelijk voorgesteld hoe hij den naam te weten kwam van Wangei, een der vijf mannen, die hij in zijn glorie-tijd gesneld had:

$\mathrm{Hij}$ had dan aan de Digoel een jongen man gegrepen en vastgehouden tot er meer hulp kwam opdagen. Een paar vrienden en familieleden waren spoedig bij hem en hielden den man vast met den rug op den grond.

Kalmoe zelf was toen opgestaan, had zich over het slachtoffer heengebogen, en met een goedige tinteling in de oogen had hij hem zéér kalm gezegd:

« Wees toch niet bang, wij willen U geen kwaad, gij zijt mijn kind, mijn zoon!» en naar het strand wijzend: wij gaan samen dáár heen, daar is het goed, zéér goed!» Zoo praatte hij een tijdje met den armen man en toen hij zag, dat zijne goedige 
woorden den ongelukkige kalmeerden, had hij gevraagd: igiz te ékab ó? Welke is toch uw naam? Hoe heet gij? Na nog eens vragen en hervragen had de man eindelijk gezegd: Wa ngei. Was dat zijn naam? volgens $\mathrm{Kalmoe}$ wel.

*Oh! zijt gij Wangei, Wangei, Wangei ka,, en tot zijne makkers - evenals hij de ooren gespitst: Wangei! En allen mompelden: Wangei, Wangei, om den naam diep in hun geheugen te prenten, hem toch maar niet te vergeten, nog honderden malen zouden zij het dien dag en de volgende dagen herhalen: Wangei!

En, Wangei, hebt ge nog een anderen naam?

Toen het slachtoffer hierop niet meer reageerde had $\mathrm{Kalmoe}$ hem met zijn sok (bamboe-mes) dat hij tot dan toe achter zijn rug in de hand hield het hoofd afgesneden en wel zoo laag mogelijk in den hals. Nu was de huichelachtige glimlach van zijn gezicht verdwenen en maakte plaats voor een harden grijns, terwijl hij voordeed hoe hij met de vlijmscherpe 'sok, den man den hals doorsneed tot op het been, dan het bloedend hoofd bij de haren nam, met een harden draai-ruk den nekwervel doorbrak en de romp met een verachtelijken schop van zich afstampte.

De sok is een bamboe. Men snijdt er een latje uit, pelt er een reepje af en heeft dan een vlijmscherp mes, dat beter dan onze messen vleesch snijdt.

Bij het onthalzen - 't is al wreed genoeg op zich zelf komt verder geen vrijwillig-langzame foltering. Ze doen het kort en goed. Daarenboven zeggen zij, dat zij alleen het ziellooze lichaam onthalzen, de sarab. De ziel is er dan al uit!

't Moet een vreeselijk gezicht zijn dat snellen: de oogen puilen uit en de tong valt diep uit den mond. Dappere slachtoffers bieden daarbij onversaagd hun hoofd aan, recht op. Er zijn er die staande onthalsd worden. Het bloed spuit hoog op uit de slagaders. De romp springt soms op en 't gebeurt dat de armen in een laatsten greep een der snellers omvatten, dan moet men die armen lam slaan anders laten ze niet los hoorde ik beweren. Het onthalzen was het werk der ouderen, der samb-anim. Was er geen $s a m b-a n e m$ in de buurt dan deed men het zelf.

Kop en naam zijn voor den vanger, den hakev-anem. 


\section{Menschen-eterij.}

Let wel dat ik hier steeds spreek over het snellen door Marindanim, want de bewoners van de Digoel- en de Eilanden-rivier b.v. zijn wel degelijk menscheneters in den gewonen zin des woords. Daar worden de slachtoffers gesneld en geheel opgegeten.

De kaja ${ }^{2}$ ging niet op sneltocht om menschenvleesch te hebben.

Alleen de toovenaars, de jemessåv-anim maken hierop eene uitzondering. $\mathrm{Zij}$ eten menschenvleesch en nemen stukken mee, vooral voorarmen en onderbeenen, ook sommige andere lichaamsdeelen noodig als ingredient bij hunne tooverkunsten.

In Okaba werd vroeger door een man een stuk menschen-vet bewaard. Bij ziekte werd een stukje daarvan meegebakken in den sago-koek waarvan ieder dan een brok kreeg.

Van de koppen zelf werd het vleesch, wanneer het vet was, gegeten. Hersenen en oogen at men niet.

Kalmoe vertelde ons, dat zij wel eens van de slachtoffers aten, wanneer men in langen tijd geen vleesch had gehad.

Verschillende dorpen hielden er in dit opzicht verschillende gewoonten op na.

De leden der imo-sekte waren over 't algemeen wreeder dan de majo's. De Sangaseeërs b.v. snelden ook kinderen, bakten menschenvleesch in sagokoeken en gaven het aan hunne kinderen, zeggend dat het $\mathrm{kei}=$ casuaris was.

Ik heb zelf een geroosterden half afgekluifden voorarm gezien afkomstig van Sangasee. De hand was door hen meegebracht en bewaard.

Een imo-lid van Mēwi: Widoei, bracht ook een arm mee van den sneltocht. Die wreede tropheeën deden dienst als lugubere versiering bij het koppenfeest.

Ook is het zeker, dat zij bij zulke gelegenheid meer dan eens de lijken der slachtoffers ontleedden. Maar dit niet zoo zeer uit wreedheid dan wel uit nieuwsgierigheid, om te zien hoe een mensch er van binnen uitziet; zij deden op hunne manier aan anatomie.

Sommige individuen zijn veel wreeder dan andere, ook dat is een feit. Widoei van Me exi was een echte woesteling. Hij had een zoon van \pm 13 : Mooih, dien hij meenam op sneltocht. Bij den overval van een dorp plaatste hij zich met Mooih bij de deur van een der huizen. Ook Mooih ving een 
mensch, die hem door vader werd toegeduwd. Na het snellen sneed Widoei de gewrichten door van knie en elleboog der slachtoffers. En men zag Mooih met de bloedende resten op zijn schouders aankomen en er uit overmoed rechts en links in bijten! - Toch was Mooih een aardige schrandere Patoer met heldere oogen en gullen lach, toen hij nog niet op sneltocht geweest was. Veel kwam hij toen bij ons aan huis. Daarna nooit meer! en sinds - ik zag hem slechts zelden in het dorp ligt voor mij eene dierlijke wreedheid op zijn gezicht en wekt zijne ranke verschijning van opgesmukten jongen man afkeer bij mij.

Nog meer is er op die sneltochten gebeurd, waarover niet gesproken wordt, waarover $\mathrm{zij}$ zich schamen te spreken, vooral met vreemden. Een feit is het, dat men soms jonge vrouwen niet aanstonds snelde, maar later, men nam ze eerst mee naar het dorp om ze daar op eene afschuwelijke wijze te misbruiken. Dat gebeurde o.m. nog in 1916 toen er Jee-anim gesneld werden door de Oenoem-en Teepas-anim van de bovenBian, en in 1919 toen de lui van Waramoen snelden in Jaan, een tuin-kampong van Jee-menschen.

't Bewijst wel, hoe diep dit volk gezonken was op moreel gebied, dat men dat alles gewoon en geoorloofd scheen te vinden; tegenover de $\mathrm{ikom}$ scheen alles te mogen, men lachte met dat alles, dat waren immers geen menschen!

\section{Het prepareeren der koppen.}

Op de Digoel neemt men alleen de scalp en vult die daarna op, zoodat de kop-vorm vrijwel verloren gaat.

De Marind-anim maakten er met veel zorg en werk mahod van: mooie(!) geprepareerde gesnelde hoofden. "Mooi, Toean!» zei mij Bonang van Boeti.

De lezer vergeve mij onderstaande wel wat realistische beschrijving, ze is trouwens niet van mij maar van Bonang z.g.

Hoe prepareerde men de koppen?

Eerst maakte men eene snee van in den hals tot op de hoofdkruin, maakte de huid (die vrij dik is) aan de kanten los en stroopte dan heel de scalp er af, men spande ze zoolang op eene klapper noot en liet ze in de zon wat drogen. Dan maakte men de schedel zuiver, sneed alle vleesch er af, stak de oogen uit en maakte de hersenpan leeg. Om dit laatste vlugger en 
beter gedaan te krijgen verruimde men de holte onder in den schedel. Men stak als neustop eene rotanlus in de neusholte en legde tevens een plat reepje rotan van den neus over het voorhoofd en twee dito reepjes boven de oogholten waarvan men de uiteinden vastmaakte aan het wangbeen. In de oog- en neusholten stopte men gaba ${ }^{2}$-merg. De holten der wangen vulde men op met klei en boetseerde het zoo getrouw mogelijk naar de natuur. Dan hing men de schedels bij groote vuren te drogen omwond het kinnenbak met biezen en trok er daarna zorgvuldig de scalp weer overheen. De groote snede en de oogholten werden met rotan-vezels dichtgenaaid. Als alles goed strak zat bond men de scalp onder dicht. Op de oogen plakte men soms kleine oogvormige paarlemoer-scherven.

Later vlocht men over het voorhoofd, achter de ooren door, om het hoofd heen een breeden harden band van rotan-reepjes, daaraan over heel den kop een netje en aan dat netje een grooten bundel haarverlengsels soms wel $75 \mathrm{cM}$. lang. Opgesierd met pluimen kraaltjes en kransjes, 't gezicht rood en zwart beschilderd waren ze volgens Bonang héél mooi. Net of het levende koppen waren, Toean! Die lus door den neus geeft daaraan niet alleen een meer natuurlijken vorm maar dient tevens om den kop op te hangen. Men hangt de gesnelde hoofden op aan den neus, wat een vreemd gezicht is. Iemand, die het niet weet, denkt er niet aan dat het menschenkoppen zijn die daar hangen. Eens in Alakoe liep ik er bijna met mijn gezicht tegenaan.

De ooren der gesnelde hoofden zijn opvallend klein, dat komt omdat alleen het vel daarvan overblijft.

De eerste preparatie, zoo juist beschreven, moet dadelijk gebeuren, op den snel-dag zelf. De opsmuk, het aanvlechten etc. daarvoor heeft men al den tijd wanneer men weer te huis is.

Zooals ik reeds zeide wordt de hals mee afgesneden om eene groote scalp te hebben, zoodat men den kop onder goed dichtbinden kan. De nekwervels worden ook zorgvuldig bewaard, waarom zullen wij later zien.

\section{De terugtocht.}

Langer dan noodig is blijft men niet in de buurt. Wat waarde heeft wordt als trophee meegenomen: lansen, pijlen, bogen, roeispanen, mandjes, korfjes, steenen bijlen, paradijsvogels enz. de nabije tuinen worden geplunderd. 
Blij wordt nu de terugtocht aanvaard.

De geroofde kinderen, zoo men ze al niet draagt, moeten midden in de rij loopen, zoodat ze niet kunnen ontsnappen. Wijl zij nog zoo klein zijn en men héél goed voor hen is, bestaat er na een paar dagreizen geen gevaar meer dat de kinderen hen ontloopen.

Gewoonlijk gaat de terugtocht vlugger dan de heenreis. Het doel is bereikt, het nieuws is er af, ze verlangen weer naar huis, naar goed eten en drinken, naar wati, naar klappernoten, naar 't gewone kalme dagelijksche leven met zijne vele rusturen in het mulle, rulle duinzand, met zijn gezellig geknutsel en gepraat in de schaduw der klappers aan de zee.

Doev: het zeestrand! o zij verlangen zoo het weer te zien.

En als zij eindelijk de zee zien blinken tusschen de boomen dan roepen allen doev-ah-oh! wat men best zou vertalen «leve het zeestrand!» Van b!ijdschap en aandoening hebben velen de tranen in de oogen!

$\mathrm{Op}$ den terugtorht maken zij groote dagreizen maar vinden toch nog tijd voor jacht en vischvangst. Komen zij een bevriend dorp voorbij, dan worden zij daar alvast bewonderd en getracteerd. Men feest en danst en verslaapt er enkele dagen en nachten.

\section{De tehuiskomst.}

Een paar dagen te voren heeft een boodschapper de blijde tijding reeds gebracht: de snellers zijn terug!

De thuis-blijvers brengen nu alles voor de ontvangst, den blijden intocht, in gereedheid. Men haalt pisang en wati en doet vele jonge klappers af. In de nabijheid van het dorp wordt de weg, dien de snellers zullen volgen, met kleurige krotons beplant, langs een blij- versierden weg moeten de overwinnaars hunne intrede doen.

Maar ik laat Bonang zelf vertellen, hoe hij en zijne makkers verwelkomd werden toen $z$ ij terugkeerden van een sneltocht ver over de Engelsche grens:

"Wij waren ontroerd, sommigen weenden toen wij in de verte ons dorp terugzagen. Vele menschen stonden op het strand, sommigen kwamen ons te gemoet, omarmden hunne broers en verwanten en ontlastten hen van alle vracht.

Bij het dorp zelf kwamen wij allen tegelijk aan: die uit de booten en zij die te voet gingen. Een weg was op het strand Dl. 79 . 
afgeteekend met kroton-takjes, beplant met kladi, bestrooid met sirih-katjes, pinang, oem (waterlelies) en groene waterplantjes. Links en rechts stonden in twee rijen de vrouwen, moeders en dochters gereed met smakelijke sago- en heerlijke pisang-koeken!"

De koppen werden in een mannenhuis (van waar het initiatief uitging) opgehangen, ook hing men daar c.q. de meegebrachte armen, de nekwervels, de meegebrachte wapens en rotan.

Daarop volgde eene algemeene omarming, waarbij veel tranen vloeiden. Men had elkaar zóó veel te vertellen!

Allen waren vol blijdschap omdat de tocht zoo goed gelukt was en allen nu weer veilig tehuis waren. De jonge kerels sloegen elkaar op den rug van glorie en pret, kalkkokers gooiden zij stuk, die met een knal uiteensprongen zoodat de kalk als eene witte wolk uiteenstoof. Dat was hún vuurwerk!

Het huis waar de koppen opgehangen waren werd ondertusschen sa or verklaard. Men kon daar de koppen gaan zien. Velen kwamen kijken. Vooral koppen met baarden werden bewonderd.

Sa or beteekent zooveel als verboden terrein, 't maakt eene plaats in zekeren zin heilig. Legt men bijv. saor op een klapper-complex, dan mag men daar geene noten plukken of rapen.

Hier maakte dat anim-saor het mannenhuis tot iets geheimzinnigs, waar slechts ernst paste. Men mocht er dan ook niet spreken. In alle stilte kwam men - van verre soms - daar den buit bewonderen. 't Is te begrijpen dat zulks vooral op kinderen diepen indruk makte.

Men prees de snellers, hen vooral die een kop bemachtigd hadden. Alles werd haarfijn verteld — dit was nog eens nieuws! natuurlijk met de noodige overdrijving er bij en veel wat wij wreed maar zij grappig vinden.

En de bewonderaars zeiden: teepo-ti ikom-isāk ah oh! jullie kennen het! Wij gaan ook binnenkort!

De eerste dagen werd er natuurlijk niets gedaan, wel door de vrouwen, want sago, versche sago moet er nu zeker zijn; maar de mannen vierden dagen en weken lang de blijde tehuiskomst met praat en dans, met veel wati en nog meer noe: slapen!

Waren zij met de booten eene rivier opgeweest om te snellen dan kwamen zij stroom mee en uit alle macht pagaaiende terug. 
Zij hadden daarbij een schoonen geweldigen pagaai-zang, een echt triomf-lied, dat zij zongen uit volle borst; met de regelmatig op en neergaande roeispanen sloegen zij staande de maat tegen den dofklinkenden kant van de boot.

Eens dat wij met onze jongens de rivier afzakten zongen zij dat lied. 't Was indrukwekkend en wij vlogen vooruit.

\section{Voorbereiding tot het Koppenfeest.}

't Moest nu groot feest worden, jaba angei, en dat vraagt veel voorbereiding. Haast heeft men niet. Men wacht soms een jaar en langer om het feest te vieren. Wanneer de nieuwe tuinen volop vrucht geven is het de goede tijd, dan kan men geuren met veel eten, uitpakken met zijn rijkdom. - De voorbereidingstijd kan in verschillende termijnen verdeeld worden. Wij zullen hier kort zijn:

Soeba (= bamboe). Men haalt veel bamboe om het feestterrein 'te omheinen, 't geraamte dier omheining is van bamboe, men vult dat aan met dor klapper- en sago-blad.

De vorm van het feestterrein was meestal een langwerpig vierkant, soms $100 \mathrm{M}$. $\times 50 \mathrm{M}$. Het besproken mannenhuis met enkele andere huizen valt er binnen.

Essara (britsen). Men maakt van bamboe en gaba ${ }^{2}$ zit- en slaapbritsen aan den binnenkant der omheining over heel de lengte en bouwt daarover een afdak.

Takav = brandhout. Men haalt veel brandhout voor de groote vuren die noodig zullen zijn om de groote feestkoeken te bakken (ik heb er gezien van $1 \frac{1}{2} \times 4$ M. !).

Sakai. Dit beteekent: termieten-nest. Bij gebrek aan steenen haalt men harde brokken sakei. Men zal ze heet stoken en daartusschen de groote koeken bakken.

$\mathrm{D} \overline{\mathrm{a}}$ hore $=$ sago kloppen. Groote voorraden worden klaargemaakt.

Beisam. Der mannen haartooi wordt in orde gebracht, men vlecht hun haarverlengsels aan. Ook de dames krijgen eene nieuwe coiffure. Een werk dat véél tijd vraagt.

Dirari $=$ waterkokers van bamboe, worden extra-groot klaar gemaakt. Men heeft ze noodig voor het klaarmaken der reuzenkoeken.

A hat en bes. Hard-houten kapstokken en knuppels worden aan de rivier gehaald. Knuppels om c. q. varkens dood te slaan; 
kapstokken, onmisbaar bij een $\mathrm{kaja}^{2}$ feest, om daaraan mandjes, eten, waterkokers, kalkkalebassen enz. op te hangen, dan wordt er in de drukte niets onder den voet geloopen en honden en varkens kunnen er niet aankomen.

$\mathrm{K} a \mathrm{v}$ manop meb: men rooit de groote aardappelen en hangt ze op rondom het feestterrein.

Enkele hooge bamboes, waaraan klappers en klapperblad doen als vlaggestokken dienst. Daaraan ziet men van verre: 't wordt kermis!

Roeg (= ketapan). Men kapt een ketapan en snoeit hem. Men vlecht twee, drie platformen aan de stersgewijs gegroeide takken. De roeg wordt met veel pret en zang naar het midden van het feestterrein gebracht en daar geplant. - Soms werden bij het feest de koppen daaraan gehangen maar meestal maakte men daarvoor een aparten vork, koei-ahat, \pm 3 meter hoog en kleurig beschilderd.

Koemboe. 't Feest is dichtbij: men haalt veel klappernoten waarvan men het vleesch raspen zal voor de feestkoeken.

Vier dagen jacht gaan onmiddellijk het groote feest vooraf want er moet veel vleesch zijn; kangoeroe's zijn er altijd te krijgen. Soms slacht men ook varkens.

Terwijl de mannen op jacht zijn halen de vrouwen de vruchten uit de tuinen: pisang, kladi, pinang, enz.... ook veel krotons ter versiering en groen pisangblad waarin de groote sagokoeken te bakken worden gelegd tusschen gloeiend gestookte steenen en sakei.

\section{Het Koppen-feest (koei - angei).}

Het feest wordt geopend iets vóór zons-ondergang door de

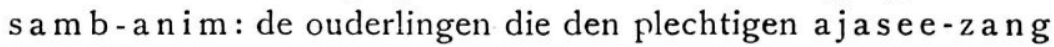
aanheffen op maat van zwaren tromslag. De koppen hangen in hun midden.

Later gaat de ajasee over in den wasipè, gezongen door de mannen en éwati's, heel den nacht door. De koppen hangen in hun midden, daaromheen staat een groote kring tromslagers, achter hen dicht opeen de zangers. $Z_{\mathrm{ij}}$ zingen met enthousiasme, elke tromslag doet een rilling gaan door heel den groep, alles beweegt en knikt, alle veeren wuiven op de maat van de trommen. Dat duurt zoo tot de zon op is.

Daarna eten ze en slapen den heelen dag. 
Den tweeden nacht is het de clou, de $s a m b-z i$, de groote zang. Een wild triomflied dat steeds en steeds herhaald wordt. Meer en meer komen de zangers onder den indruk. 't Is iets machtigs. Als men er dicht bij staat, dringt de tromslag $U$ door merg en been.

Groepsgewijze komen de naburige dorpen, den grooten $z \bar{i}$ zingend, over het zeestrand naar het feestend dorp. Men loopt elkaar met hel brandende fakkels te gemoet, sommigen loopdansen - hoog houdend de fakkels — rond de zingende groepen. Een woest en wild maar kleur-rijk en fantastisch tafereel.

De groepen houden stand op vrij korten afstand van elkander, elk zingt zijn lied, zonder zich om de anderen te bekreunen.

Boven de hoofdgroep rijst de roege, de ketapan, pisang en beteltrossen hangen er aan. De meest gevierde jonge man (in Okaba: Kamogem) klimt er op langs een bamboe. Hij staat te dansen op het platform, als een held hoog boven zijne trommende en zingende dorpsgenooten. 't Was indrukwekkend: onder die triomf-zingende groep, mannelijk en machtig; en boven: dien rythmisch bewegenden slanken opgesierden man, wiens donker silhouet zich afteekende op den schoonsten achtergrond, dien men zich denken kan: een dofblauwen hemel met fonkelende sterren!

's Morgens vroeg is er optocht van mooi opgesierde jongelui. De zon is nog niet op. Met fakkellicht begeleiden moeders en zusters de opgesmukten: zij dragen op het hoofd hooge waaiers met fijne donsveertjes beplakt, soms zwiept eene elastische lat boven hun hoofd, op den punt steken paradijsvogel-flanken. Andere keeren dragen zij vogels, kaaimannen, honden op het. hoofd, elk volgens zijn totem en ondertusschen zingen de ouden op de graven een rouwzang.

Soms ging een koppen-feest samen met een wårti zi, een weiko, een soeba-mit of een varkensfeest. Elk dier zangwijzen bracht eigen dans en weer andere versieringen mee. ' $t$ Is hier de plaats niet om daar verder op in te gaan.

Den derden nacht is er nog eens kleine dans ngat-zi. En dan is het afgeloopen. Zij zijn moe. De stemmen zijn op. De kermis is uit, de kermis met veel eten en extra-drinken, met veel dans en veel zang, met veel pret, maar lang niet altijd onschuldige. Zonder zondig vermaak kunnen de volwassen kaja's zich geen feest voorstellen. Als het bij ons op de kermissen 
vaak zoo was en nog is, hoeveel te meer hier, waar geen geloof was aan eene Hoogere Macht die rekenschap vraagt, waar hooger genot ontbrak, waar het lagere dierlijk genot als het meest begeerenswaardige wordt nagestreefd.

\section{Wat doet men daarna met de koppen en de nekwervels?}

$\mathrm{Na}$ het feest worden de koppen in de respectievelijke mannenhuizen opgehangen, meest binnen boven den ingang, ook wel eens buiten onder het overstekend dak. $\mathrm{Na}$ een paar jaar was de scalp verweerd en opgevreten door de mieren. Men hing dan de schedels tot trossen in de huizen, meest in 't midden bij den hoofdpaal der hut. Meermalen vond men oude schedels buiten op een stok of op de omheining.

Meer waarde hadden de kinnebakken en die werden zorgvuldig bewaard. Vaak werden zij tot één rits samengebonden tusschen een gespleten rotan.

In Kavoe zja, boven op de Merauke-rivier, trof ik in het ééne groote huis $(20 \times 20$ M.) waarin heel het dorp woonde, eene groote rotanlus aan, bevestigd aan den hoofdpaal. Daaraan waren 34 kinnebakken bevestigd. Men had er ook pijl- en lanspunten aangebonden waarmee men de slachtoffers geraakt had. De 34 schedels hingen er bij, sommige droegen nog de sporen van geweld, één o.a. was door een knotsslag ingedeukt. Ook hingen bij dien hoofdpaal nog allerlei mandjes vol nekwervels en ander gebeente, zeker af komstig van de gesnelden. Daar át men ook de slachtoffers, dat was duidelijk.

Dit jaar nog zag ik op de boven-Koembe een man die heel gemoedelijk een menschelijk kinnebak aan zijn kalkkoker had gebonden.

De kinnebakken werden dus goed bewaard en de eigenaars kenden er de geheele geschiedenis van die zij gaarne aan hunne kinderen vertelden.

Bij de inwijding van een nieuw huis, een nieuw mannenhuis, was er een heel ceremonieel. Dan werd een boog van kinnebakken boven de deur gebonden, de schedels werden er in opgehangen en elke man hing boven zijne slaapplaats zijne collectie nekwervels aan een snoer geregen.

Men bewaart nog de herinnering aan een groot koppenfeest in Borem, waar de mannen van dat toen groote dorp heel het 
feestterrein rondom hadden versierd met eene guirlande van nekwervels! (Men droeg die wervels ook wel als borstversiering).

Daaraan kan men ongeveer schatten hoeveel slachtoffers er vielen! 't Was een wedstrijd wie 't meest koppen halen zou! In het snellen moet men de oorzaak zoeken van de zoo dunne bevolking van dit groote land.

De oude Dōm-tamoe van Boeti had hier in de buurt van den Mangat-stam 4 andere kleine stammen gekend, die tijdens zijn leven geheel uitgemoord werden.

\section{Is snellen volgens hen moreel kwaad?}

Alles wat volgens hen moreel kwaad is heet doer.

Welnu snellen was niet doer, dat mocht niet alleen, dat moest!

Snellen bij bevriende stammen, dát was doer.

Maar snellen bij de ikom was mannenplicht, wanneer de namen op waren. Men groeide op in die overtuiging.

Voortdurend werd men daarin bevestigd: door het feit der sneltochten zelf, door de legenden, tot zelfs in de spelen der kinderen was het doorgedrongen.

Kinderen belegden als spel sneltochtvergadering, en het ging daarbij heel ernstig toe.

De patoers schoten met hunne kapan (pijlen waarop boven een kop van bamboe) mooie kleine vogeltjes, sneden ze de halsjes af, stroopten de huid van de kopjes, krabden die schoon, haalden de hersens er uit, haalden de huid er weer over, staken een dunnen draad door de luchtgaten der bekjes en hadden dan wat ze noemden waningap mahod $=$ mooie gesnelde kopjes!

Uit een grashalm vlochten zij pyramide-vormige miniatuurkorfjes; met de graspluim er aan leek het iets op een mahod, en zóó noemden zij ze ook: gesnelde koppen.

Heel hun leven, hunne geschiedenis, hunne legenden waren doortrokken van koppensnellerij.

Eens noemde Broeder van Santvoort zijne vele broers en zusters op. Een der toehoorders liet zich ontvallen: «wat zal zijn vader een groote koppenjager geweest zijn!> En dat was een compliment. De man bedacht zich echter aanstonds. Volgens ons mocht dat immers niet. En verlegen stak hij den vinger in den mond, 


\section{Over den oorsprong van dit barbaarsch gebruik.}

Laat ik eerst een paar onjuiste verhalen rechtzetten:

Merauke was pas gesticht en reeds las men in «de Aarde en hare Volken» dat de jonge kaja ${ }^{2}$-man één of meer koppen moest hebben gesneld om eene vrouw te krijgen. Dat moge elders zoo zijn, bij de Marind-anim heb ik daar nooit iets van gemerkt.

Anderen die Kruyt gelezen hadden pasten zijne theorie over het animisme toe op den kaja $^{2}$ koppensneller. Hij ging volgens hen op sneltocht om zich te verrijken met de zielestof van den verslagene en die zielestof met den naam over te brengen op zijn kind.

Ik vond hier niets wat daarop wees. Integendeel, zij beweren juist dat de ziel al weg is wanneer men tot het onthalzen overgaat! en anim bake zijn niet eens menschen!

't Wil mij voorkomen dat het koppensnellen hier gegroeid is uit den oorlogstoestand waarin deze stammen steeds verkeerden.

Elk wil zijn gebied beschermen en beveiligen, geen beter middel om dat te bereiken dan vrees in te boezemen aan de omwonenden. Stilaan sloot men vrede met de naaste buren.

Wraakgevoel speelde hier ook een grooten rol. Verleden jaar nog werd Avai gestraft maar later bleek dat hunne aanklagers eerst bij hen waren gaan snellen!

Waarschijnlijk heeft men eerst de koppen slechts als trophee meegenomen, als het bewijs dat men een vijand verslagen had.

Men gaf en geeft nog - om ze beter te onthouden - de namen van deema's aan booten en trommen, de namen van bevriende plaatsen aan de honden, de namen der plaatsen uit het snel-gebied aan de varkens. 't Lag wel in de lijn de namen der verslagenen te geven aan de kinderen van den stam. Daarom trachtte men de namen der slachtoffers te weten te komen. Zoo was de naam van het kind eene blijvende herinnering aan vaders dapperheid. Die namen werden de echte namen en het halen dier namen hoofddoel van de tochten op vijandig gebied. Waren de namen op dan moest men andere hebben. Het voldoen aan dien plicht was meteen voldoen aan den zucht naar strijd en avontuur den primitieven eigen. Hoe gaarne zij er op uit togen - en nu nog zouden gaarne gaan! - heeft men kunnen opmaken uit dit opstel, waarin niets werd verzonnen maar alles, elk detail gewetensvol naar het leven geteekend.

Merauke, December 1920. 